\title{
Improving Students' Writing Descriptive Text Through Digital Storytelling Technique
}

\author{
Karisma Erikson Tarigan ${ }^{1}$, Liana $^{1}$

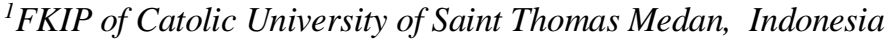 \\ email: erick_tarigan2006@yahoo.com
}

\begin{abstract}
The most difficult part of writing is students could not organize the development of their ideas and the purpose of the text.Digital storytelling is one of the multimedia to improve students' writing competency. The main objective of this research is to prove whether the digital storytelling enhances and improve students writing competency. The study uses classroom action research (CAR). The data in this study are quantitative and qualitative data. The quantitative data will be collected by using the essay test. The qualitative data will be collected by using observation, field notes, and questionnaire.The results of the use of digital storytelling in writing text significantly increased by using digital storytelling. The score of students' writing descriptive text kept increasing from pre-test until post-test. It was proved by the data which showed that the mean of the students' score in post-test II (86.4) was higher than the post-test I (72.2), and also higher than the pre-test (54.8). in addition, the response of student in using digital storytelling in the agree category, it can be seen from the frequencies of item 110 (52.88\%).Therefore, Digital Storytelling significantly improves students' score in writing Descriptive Text. Furthermore, it can be concluded that Digital Storytelling is effective to be used in teaching writing skill, especially in Descriptive Text.
\end{abstract}

Keywords: digital storytelling; writing skill; student's competency

\section{Introduction}

The subject of English writing is present throughout the teaching and learning in the education curriculum in Indonesia. Teacher in every content area can use writing as a powerful learning tool to help students' reflect on what they read, what they listen to, and work out their own thinking and through a process on paper. Furthermore, in the process of teaching and learning English as a foreign language, writing is very complex and the most crucial skill in learning English. As Richard and Renandya (2002) argued "there is no doubt that writing is the most difficult skill for second language learners to master". The difficulty of complexity writing text can be seen from students' ignorance to the mechanical requirements such spelling, punctuation in making the cohesion and the coherence of writing clearly to get the purpose of the text. Mather, et. al. (2009) state that when learning to write, students may have trouble generating content, creating organizing structures, formulating goals, executing the mechanicals aspects of writing, and revising the text and reformulating goals. Some students struggle primarily with spelling, whereas others have trouble formulating their ideas into coherent messages. Therefore, it is crucial for teachers to facilitate 
students with some effective techniques and tools. And one of the tools is by using multimedia to present a text. The learning media contributes to the teaching and learning process. As what Xie and Huang (2012) states "With the development of information technology and the media development, the traditional story of application in teaching is increasingly reduced, technology during the presentation of the story began to play a role, so that the way of telling the story is more and more abundant, spreading more and more widely."

In line with the story, Miller (2010) states that students love putting the stories together with images and music on the computer, but before they get there, they must do the writing. Writing is thinking, so through writing, they find out what they want to say and how they want to say it in the scripts. Digital storytelling is one of the multimedia to improve students' writing competency. As Ohler (2008) defines "Digital storytelling is also an effective vehicle for teaching another kind of literacy that is becoming increasingly important as our students spend more and more time in a media-saturated culture: media literacy." Through digital storytelling, students can present the content of writing clearly, as well as the writer's purpose of the text. Considering the issues that have been described, the writer tried to use multimedia which can encourage the students to enhance and improve their writing competency in the First Year of English Language Study Program Teacher Training and Education Faculty Catholic University of Saint Thomas Medan by using Digital Storytelling. It is believed that digital storytelling provides students with a flexible learning environment where they can work collaboratively and consider the various issue critically while applying their communication and technology skills. Throughout the active learning process that digital storytelling provides, students can improve their ability to think and develop relations between the texts, story tellers, and themselves; which enhances their understanding of the issues, and their ability to listen and interact with others.

\section{Review of Literature}

\subsection{The Importance of Writing}

Kern (2000) states writing is essential to academic language learning for a number of reasons.

1. In designing through writing, learners develop their ability to think explicitly about how to organize and express their thoughts, feelings, and ideas in ways compatible with envisioned readers' expectations.

2. Just as reading allows learners to focus their attention on their relationships among forms, writing allows learners to create and reshape meaning through explicit manipulation of forms. Writing thus provides an excellent platform for learners to test hypotheses about the new language. By 'trying out' different words, syntactic structures, styles, and organizational patterns, and by considering the effects that such manipulation might have own meaning, learners can broaden their communicative potential in the language. Thinking about the complex relations of forms and meaning in their own writing may in turn predispose them to be more sensitive to form or meaning relationships in the texts they read in the foreign language.

3. Writing provides time for learners to process meaning. Many foreign language learners students find writing easier and less anxiety producing than speaking, simply because 
they have time to think. When speaking, their attention is divided among many things, including the development of an idea, the mapping of that idea onto appropriate structures (and perhaps silent rehearsal of the utterance), and the monitoring of conversational turns so that they can find an appropriate place to interject their comments. While these processes operate smoothly when one is speaking one's native language, they are less efficient when one is learning a new language. When writing, students need not worry about turns, pronunciation, or keeping an idea (and its articulation) rehearsed in memory. They are free to take the time they need to get their message across in a form they find acceptable. Furthermore, when they are given the chance to express and respond to ideas in writing, students are often able to engage more effectively in subsequent oral discussions because their ideas have already been at least partially developed and articulated, allowing them to focus more attention on their oral delivery.

4. Writing allows learners' language use to go beyond purely 'functional' communication, making it possible to create imagined worlds of their own design.

\subsection{Teaching Writing}

Hale, et. al. (2008) state that good writing does not rely on grammatical and lexical accuracy but also on the creativity in context and the logical flow of sentences. In order to write coherent, well-structured and essays, the writers have to be creative and concentrate on the content as well. First, teachers can help students raise their awareness of how to organize English writing, and how units of sentences and paragraphs are connected with one another to form meaningful text. By recognizing the importance of coherency in their writing, the students can dedicate themselves to the ideas or message that they are trying to convey.

\subsection{Digital Storytelling Technique}

Kengue and Jared (2015) define "digital storytelling is a technique that forces students to decide the (impressive and tell able) stories, and to solve the problem of processing the digital story that combine visuals, linguistics, music, and narration to achieve desired outcomes. Hence, digital storytelling requires and improves the skills of synthesis, creativity, conducting research, and critical thinking." Lee (2017) explains that a digital story allows students to work individually or in small groups to produce a digital project that combines writing, digital images, and digital video. A digital story is a personal narrative (about a personal experience or personal reflection on a topic) presented orally in the first person and combined with multimedia like photos, music, and other sounds. A digital story can be viewed as a merger between traditional storytelling and the use of multimedia technology. Digital storytelling is storytelling that contains computer-based images, video clips, audio narration, and texts. With the popular and easy use of computers, smart phones, tablets, digital cameras and video recorders, it is not difficult for the students nowadays to create their stories digitally with some training. Moreover, with access to the Internet and Web 2.0 tools, digital stories can be created, shared, or co authored online with anyone, anywhere. Okada and Alexandra (2012) state that digital storytelling has the potential to enhance cooperation and collaboration in the classroom, because students can be more engaged when they work together to create a digital story. According to Slavin (1996) collaborative learning leads students to encourage themselves support each other and work together to achieve an 
academic goal. Students can obtain a range of skills through the story of creation process, while they work collaboratively and engage with the digital content.

\subsection{Teaching Writing through Digital Storytelling Technique}

$\mathrm{Li}$ (2015) basic steps of creating a digital story:

Step I: collect the data

1. Select a topic for digital story and create the folder on the desktop to store the materials found for the story.

2. Search for image resources for the story; for example, pictures, drawings, photographs, maps, and charts; save these resources in the folder.

3. Locate audio resources, such as music, speeches, interviews, and sound effects; save these resources in the folder.

4. Locate informational content, which might come from the websites, word processed documents, or PowerPoint slides; save these resources in the folder.

5. Decide the purpose of the story, that is, to inform, convince, provoke, question.

Steps II: Create the story

1. Select the images to be used for your digital story.

2. Select the audio to be used for your digital story.

3. Select the content and text to be used for your digital story.

4. Import the images into Photo Story (Note: Photo Story is a free software available from download from Microsoft).

5. Import audio into Photo Story.

6. Modify images and image order as needed.

7. Use a computer microphone and record the narration of the script and import the narration into Photo Story.

8. Finalize the digital story and save it as a Windows Media Video File.

\section{Research Methodology}

The study uses classroom action research (CAR). The data of this study are quantitative and qualitative data. The quantitative data will be collected by using essay test. The qualitative data will be collected by using observation, field notes and questionnaire. This study also involves four phases in each cycle which are essential as proposed by kemmis and Mc Taggart (in Burns, 2010). According to Burns (2010:5) "action research is carried out by teachers in their context, in their classrooms. Teachers identify a problem or an area they wish to improve and based on theory or experience or a hypothesis they think of an intervention. Those phases are planning, acting, observing, and reflecting. Planning is the identification process of problems or issues in order to compose a plan of action to bring improvements in a certain area of the research context. The action is the plan that is carefully considered one which includes some deliberate interventions into the teaching process. The next is observation. This phase involves the researcher in observing systematically the effect of the 
action and documenting all the process. The last phase is the reflection. At this phase, the researcher reflects on, evaluate and explain the effect of the action in order to make sense of what has happened and to understand the issue clearly.

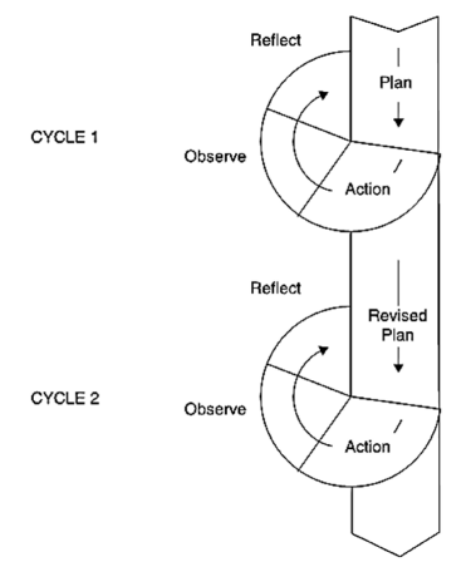

Figure 1. Cyclical Classroom Action Research (CAR) modelbased on Kemmis and McTaggrat in Burns (2010)

The subject of research is the first semester of Students University of English Language Study Program Faculty of Teachers Training and Education Catholic University of Saint Thomas North Sumatera (FKIP UNIKA).There will be three kinds of instruments used to get the data. They are observation sheet, field notes, and test form. Observation sheet and field notes will be used to get qualitative data, and to obtain quantitative data, test and questionnaire will be used.

The test is used to measure whether there will be an improvement of students' competency in writing skill by using digital storytelling. The kind of test is in the essay form. The questionnaire is given to know the students' motivation and response after they have been applied Digital Storytelling. The form of questionnaire is close-ended statements. Questionnaire is in the form of table which is filled out by giving sign of check mark $(\sqrt{ })$.Observation sheet is used to monitor and record the data of the students' performance and behavior during learning and teaching process in the class. The format of the observation checklist is close-ended statement. The field notes contain the descriptions and accounts of events during the implementation of digital storytelling. It can be used by the writer to determine the best actions.

The data is collected by following some procedure. In cycle one, there are four phases in collecting data are planning, action, observation, and reflection. To know the mean of students' score, the writer uses the formula by Best and Khan (2002):

$$
M=\frac{\sum \mathrm{X}}{N} \mathrm{X} 100 \%
$$

Where: $\mathrm{M}=$ the mean of students' score

$\sum \mathrm{X}=$ the total score

$\mathrm{N}=$ the total number of students who do the test 


\section{Discussion}

The improvement of the students' mean score kept increasing from the pre-test until Post-test I and Post-test II. It can be seen that the mean score of the pre-test was $54.8(54.8 \%)$, the mean score of Post-test I was $72.2(72.2 \%)$, and the last test that the Post-test II was 86.4 (84.4\%). In addition, there was $31.4 \%$ of students' improvement in writing text using digital storytelling. It can be seen from the difference of mean score from pre-test to the post-test II. The writer presented the data of mean scoring through table below:

Table 1. Mean score of the Test

\begin{tabular}{|c|c|c|c|}
\hline No. & Pretest & Post-Test I & Post-Test II \\
\hline 1 & 38 & 58 & 80 \\
\hline 2 & 84 & 68 & 95 \\
\hline 3 & 57 & 91 & 90 \\
\hline 4 & 71 & 71 & 94 \\
\hline 5 & 85 & 87 & 90 \\
\hline 6 & 58 & 75 & 80 \\
\hline 7 & 45 & 46 & 80 \\
\hline 8 & 47 & 69 & 94 \\
\hline 9 & 56 & 78 & 94 \\
\hline 10 & 39 & 72 & 80 \\
\hline 11 & 57 & 82 & 83 \\
\hline 12 & 43 & 75 & 85 \\
\hline 13 & 45 & 54 & 91 \\
\hline 14 & 34 & 71 & 89 \\
\hline 15 & 76 & 86 & 87 \\
\hline 16 & 42 & 72 & 79 \\
\hline Total & 877 & 1155 & 1386 \\
\hline Mean & 54.8 & 72.2 & 86.4 \\
\hline Percentage & $54,8 \%$ & $72,2 \%$ & $86,4 \%$ \\
\hline
\end{tabular}


The results of the use of digital storytelling in writing text was significantly increase by using digital storytelling. The score of students' writing descriptive text kept incrasing from pre-test until post-test. It was proved by the data which showed that the mean of the students' score in post-test II (86.4) was higher than the post-test I (72.2), and also higher than the pre-test (54.8). in addition, the response of student in using digital storytelling is agree, it can be seen from the frequencies of item 110 (52.88\%).

\section{Conclusion}

Using Digital Storytelling in Writing Texs Especially Descriptive Text was effective in Students' Faculty of English Education Program at Saint Thomas University Medan 2017/2018. After the writer analysis the data, it is found that the improvement of the students' total frome pre-test until post-test II $(31,6)$.Therefore, Digital Storytelling significanly improves students' score in writing Descriptives Text. Furthermore, it can be concluded that Digital Storytelling is effective to he used in teaching writing skill especially in Descriptive Text. Based on the increas of the percentage, it is found out pre-test $(54,8 \%)$, post-test I (72,2 \%), to post-test $(86,4 \%)$.

\section{References}

Best, J.W. \& Khan J.V. 2006.Research in Education.London: Pearson Education.

Burns, A. 2010.Doing Action Research in English Language Teaching. New York: Routledge Taylor and Francis Group.

Hale, et. al. 2008.Charting New Courses: Second Language Action Research in Japanese Junior and Senior High Schools. New York: Accents Asia Press.

Kern, R. 2000. Literacy and Language Teaching. Oxford: Oxford University.

Kengue\& Jared. 2015. Handbook of Research on Educational Technology Integration and Active Learning. Hershey: Information Science Reference.

Lee, I. 2017. Classroom Writing Assessment and Feedback in L2 School Contexts. Singapore: Springer.

Li, N. 2015.A Book for Every Teacher: Teaching English Language Learners. Washington: Information Age Publishing.

Mather, et. al. 2009. Writing Assessment and Instruction for Students with Learning Disabilities. San Fransisco: Jossey-Bass.

Miller, L.C. 2010. Make Me a Story: Teaching Writing through Digital Storytelling. Portland: Stenhouse Publishers.

Ohler, J. 2008. Digital Storytelling in the Classroom: New Media Pathways to Literacy, Learning, and Creativity. California: Corwin Press.

Okada \& Alexandra. 2012. Collaborative Learning 2.0: Open Educational Resources: Open Educational Resources. Hershey: Information Science Reference.

Richard, J.C., \& Renandya, W.A. 2002. Methodology in Language Teaching: An Anthology of Current Practice. Cambridge: Cambridge University.

Xie, A., \& Huang, X. 2012. Advances in Computer Science and Education. New York: Springer. 